\section{Biological Amendment, Fertilizer Rate, and Irrigation Frequency for Organic Bell Pepper Transplant Production}

\author{
Vincent M. Russo ${ }^{1}$ \\ U.S. Department of Agriculture, Agricultural Research Service, South \\ Central Agricultural Research Laboratory, P.O. Box 159, Highway 3W, \\ Lane, OK 74555
}

Additional index words. arbuscular mycorrhizae, bacteria, bell pepper, Capsicum annuum, fungus, greenhouse, medium

\begin{abstract}
Use of biological amendments in vegetable transplant production may affect plant development. Rhizosphere bacteria can alter conditions in the root zone and affect plant growth even if root tissue is not colonized. Arbuscular mycorrhizae (AM) affect plant development through symbiotic relations. Abiotic factors may mediate effects of biotic amendments. Organically certified potting medium was inoculated with a mix of Sinorhizobium sp. bacteria or a mix of AM fungi. Controls consisted of no amendment. Bell pepper, Capsicum annum L., cv. Jupiter, seed were sown in the medium and irrigated either twice a day for 3 minutes per application or three times a day for 2 minutes per application. Seedlings were treated with $8,16,24$, or $32 \mathrm{~mL} \cdot \mathrm{L}^{-1}$ of an organically certified liquid fertilizer beginning 3 weeks after sowing. Use of bacteria improved plant height and dry weight. Interactions of bacteria and fertilizer rate or irrigation regime affected plant height or dry weight. When irrigated twice a day, plants were tallest when provided $16 \mathrm{~mL} \cdot \mathrm{L}^{-1}$ fertilizer, and heaviest when provided $24 \mathrm{~mL} \cdot \mathrm{L}^{-1}$ fertilizer. When irrigated three times a day, plants were taller at the lower rates of fertilizer and heaviest at the highest rate of fertilizer. Use of $A M$ had little effect on plant height and dry weight. Most of the responses when AM was the amendment were the result of fertilizer rate and irrigation regime. When irrigated twice a day, AM-treated plants were tallest and heaviest when provided at least $24 \mathrm{~mL} \cdot \mathrm{L}^{-1}$ fertilizer. Regardless of biological amendment, plant heights were correlated with plant dry weights over fertilizer rates and irrigation regime. Use of Sinorhizobium sp. appeared to provide a benefit to the development of bell pepper transplants.
\end{abstract}

Use of transplants to establish vegetable crops in the field is an accepted practice in the United States. Research directions have focused on ways to produce transplants that meet mechanization requirements, survive field establishment, and contribute to plant health that could affect yield of plants developed from the transplants (Cantliffe, 1993; Damato and Trotta, 2000; Dufault, 1998; de Grazia et al., 2002; Hartz et al., 2002; Koller et al., 2004; Maynard, 2000; Nicola et al., 2004; Russo, 2004; Sterrett et al., 1983; Vavrina, 1998). Most of this work

Received for publication 23 Mar. 2006. Accepted for publication 26 June 2006. Mention of a trademark, vendor, or proprietary product does not constitute a guarantee or warranty of the product by the U.S. Department of Agriculture (USDA) and does not imply its approval to the exclusion of other products that may also be suitable. A USDA employee prepared the article as part of his official duties. Copyright protection under U.S. copyright law is not available for such works, and there is no copyright to transfer. The fact that the private publication in which the article appears is itself copyrighted does not affect the material that is a work product of the U.S. government, which can be freely reproduced by the public.

${ }^{1}$ To whom reprint requests should be addressed; e-mail vrusso-usda@lane-ag.org. has not examined the effects of biotic amendments on vegetable transplant production.

Arbuscular mycorrhizae (AM) are beneficial fungi that colonize roots of almost all vascular plants (Singh and Adholeya, 2002). Linderman and Davis (2001) added Glomus intraradices Schenck \& Smith, an AM fungus, to soil in containers sown with onion (Allium cepa L.) seed, and plants harvested after 10 weeks were more vigorous because of the presence of the AM fungus. When a medium was amended with coconut (Cocos nucifera L.) dust, making up $60 \%$ of the volume, inoculation with $G$. intraradices depressed development of ornamental flowers (Linderman and Davis, 2003). Addition of mycorrhizae may not benefit bell pepper production (Makus, 2005). Seedling growth of bell pepper (Capsicum annuum L.) was detrimentally affected by use of $G$. intraradices (Douds and Reider, 2003; Nemec et al., 1996). Use of AM fungi for vegetable transplant production needs clarification.

Rhizosphere bacteria can be beneficial to plant development (Glick, 2004; Lucy et al., 2004; Schulze and Pöschel, 2004; Zehnder et al., 2001). Nodule-forming bacteria (Rhizobium sp.; now Sinorhizobium sp.) allow for absorption of $\mathrm{N}$ in legumes, and nitrogenfixing bacteria can be associated with roots of nonleguminous crops (Emitiazi et al., 2003;
Shimshick and Herbert, 1979; Zahir et al., 2004). These bacteria can interact synergistically with mycorrhizal fungi to increase root colonization by both nodulation of roots and amount of nutrients available to plants (Suresh and Bagyaral, 2002). Rhizosphere bacteria have also been reported to reduce the severity of disease at later stages of development of cucurbits (Kokalis-Burelle et al., 2003). When Bacillus subtillis, another plant growth promoting bacterium, was added to transplant mixes, seedling vigor of pepper, tomato (Lycopersicon esculentum Mill.), strawberry (Fragaria chiloensis var. ananas$s a$ Duchesne), and several cucurbits, were improved (Kokalis-Burelle et al., 1999). In long-term greenhouse experiments, addition of bacteria that induce systemic acquired resistance had little effect on tomato (Vavrina and Roberts, 2004). With graminaceous crops, the need for $\mathrm{N}$ fertilizer was not reduced when free-living and endophytic $\mathrm{N}_{2}$-fixing bacteria were present (Andrews et al., 2003). In an organic system, addition of beneficial bacteria enhanced tomato yield and quality comparable with a conventional production system (Rippy et al., 2004). It is not clear whether plant growth-promoting bacteria, especially those normally considered to be symbiotic on legumes like Sinorhizobium, will benefit production and development of vegetable transplants.

Abiotic factors can affect transplant development. The amount of water and fertilizer available are examples of abiotic factors. Phosphorus rate and water stress can beneficially or detrimentally affect mycorrhizal activity and plant responses (Martin and Stutz, 2004; Waterer and Coltman, 1989).

Expanding interest in organic production of vegetables necessitated the development of production systems that meet the requirements of the National Organic Program (NOP, U.S. Department of Agriculture, Agriculture Marketing Service, 2000). Russo (2005) developed a system in which pepper transplants were grown using a completely organic system and were comparable to those produced using conventional methods.

Transplant production is fundamentally different from long-term production because there are only a few weeks from sowing seed to transplanting, and changes in the potting medium are limited to the small volume in which the seedling root system develops. The current project was undertaken to determine the efficacy of AM and Sinorhizobium sp. amendments for production of pepper seedlings, and to determine how organic fertilizer rate and irrigation frequency modify transplant growth.

\section{Material and Methods}

\section{Components common to all experiments}

The experiments were conducted in a greenhouse at Lane, Okla., from late Feb. to mid Apr. 2005. Temperatures in the greenhouse averaged $33{ }^{\circ} \mathrm{C} / 22{ }^{\circ} \mathrm{C} \pm 1{ }^{\circ} \mathrm{C}$ (day/night). More attention was directed to daytime cooling than heating because outside 
daytime temperatures in late winter and early spring in southeastern Oklahoma can reach low to high $20{ }^{\circ} \mathrm{C}$ and mid $30{ }^{\circ} \mathrm{C}$ in the greenhouse. Additional lighting with fluorescent bulbs (430 lumens $/ \mathrm{m}^{-3}$; Sun Agro, Phillips, Sommerset, N.J.) were used to provide plants with a minimum of $12 \mathrm{~h}$ of a mix of sunlight and artificial light, and lights were turned off after $12 \mathrm{~h}$ of daylight occurred. New Speedling ${ }^{\circledR}$ planting trays (American Plant Products, Oklahoma City, Okla.), $72.5 \times$ $34.5 \times 6.2 \mathrm{~cm}$ (length $\times$ width $\times$ depth), containing 128 cells per tray were used. Cell dimensions are $3.7 \times 3.7 \mathrm{~cm}$ (length $\times$ width), with each cell having a volume of $36 \mathrm{~cm}^{3}$. Trays were placed on benches made of perforated metal about $1 \mathrm{~m}$ above the floor. New plastic inserts (American Plant Products; $3.5 \times 3.5 \times 6 \mathrm{~cm}$, length $\times$ width $\times$ depth) with cell volumes of $30 \mathrm{~cm}^{3}$ were fit within cells of planting trays. Cell inserts were filled halfway with Mix \#1/LC1 potting medium [SunGro, Bellevue, Wash.; Organic Materials Review Institute (OMRI), Eugene, Ore., listed] with a water-holding capacity of $\approx 320$ $\mathrm{mL} / 1000 \mathrm{~cm}^{3}$. The major components of the medium are sphagnum, perlite, peatmoss, gypsum, and dolomitic limestone. The medium was moistened with tap water. The nutrient content of the irrigation water and the potting medium, analyzed by the Oklahoma State University Soil, Water \& Forage Analytical Laboratory, Stillwater, Okla., are described in Tables 1 and 2, respectively.

\section{Amendment}

A mix of Sinorhizobium meliloti and S. leguminosarum biovar trifolii (previously Rhizobium) bacteria, designated for use with alfalfa, and sweet, red, white, alsike, and ladino clovers (Nitragin ${ }^{\circledR}$, Milwaukee, Wisc.; 200,000,000 propagules/g) was added to the medium $(0.5 \mathrm{~g} /$ cell of the mix $)$ in 24 planting trays with a scoop having a hole diameter of $6.2 \mathrm{~mm}$ and a hole depth of $4.5 \mathrm{~mm}$. An equal number of trays without bacteria were controls. The remaining space in the cells was filled with the medium.

In other planting trays, a source of AM fungi (Myco-VAM®, Helena Chemical Co., Collierville, Tenn.; 123,300 propagules/kg; OMRI listed) was applied to the medium (0.6 $\mathrm{g} \cdot$ cell $^{-1}$ of the mix) in 24 planting trays with a scoop having a hole diameter of $11.5 \mathrm{~mm}$ and a hole depth of $10.5 \mathrm{~mm}$. Myco-VAM contains G. aggregatum (Schenck \& Smith emend. Koske), G. intraradices, and G. mosseae Gerd \& Trappe. An equal number of trays without AM were controls. The remaining space in the cells was filled with the medium.

Holes about $4 \mathrm{~mm}$ deep were punched in the medium in all trays, and two to four seed of bell pepper, cv. Jupiter, were sown in the holes and the medium tamped closed. The medium was again moistened. After $24 \mathrm{~h}$, timed irrigation was begun. Trays were exposed to two irrigation frequencies: $2 \mathrm{~min}$ per application at $9 \mathrm{AM}, 3 \mathrm{PM}$, and 6 PM daily; or 3 min per application at 9 AM and 3 PM daily. The misting system on each bench was comprised of three emitters, each of which delivered $\approx 850 \mathrm{~mL} \cdot \mathrm{min}^{-1}$ (providing $5.1 \mathrm{~L}$ daily per emitter) in a fine mist. Each bench accommodates 12 planting trays for a total 1536 cells. Each cell received $\approx 10 \mathrm{~mL}$ water daily. Cells contain $30 \mathrm{~cm}^{3}$ of medium. Over $24 \mathrm{~h}$, from after the 9 AM irrigation to before the 9 Am irrigation the next day, flow-through was about $1 \mathrm{~mL} /$ cell.

Three weeks after sowing, when emergence was $+90 \%$, plants were thinned to one plant/cell. Fertilization was begun at that time with Neptune's Harvest (Ocean Crest Seafoods, Gloucester, Maine), an OMRI listed liquid fertilizer. Before fertilizations, the container was shaken to ensure contents were well mixed. The unused material was kept in the closed container. The label on the undiluted material indicates it provides $2 \mathrm{~N}$ $3 \mathrm{P}-1 \mathrm{~K}$, derived from hydrolyzed fish and seaweed, and the recommended label rate $(1 \times)$ is $4 \mathrm{~mL} \cdot \mathrm{L}^{-1}$. The nutrient content of the $1 \times$ rate is provided in Table 2 . The fertilizer was applied at $8,16,24$, or $32 \mathrm{~mL} \cdot \mathrm{L}^{-1}$, with $1000 \mathrm{~mL}$ of each dilution in the appropriate tray. Fertilization was applied weekly for 5 weeks.

\section{Data acquisition}

At this location, it is desirable that transplants be placed slightly deeper in the ground, which requires a slightly taller plant requiring a longer period in the greenhouse.
Heights of 10 plants, chosen at random, in each tray were taken 8 weeks after sowing. The plants were removed from the trays; the medium was washed from roots using tap water and visually examined. Each plant was placed in a paper envelope, and dried in a forced air oven at $40{ }^{\circ} \mathrm{C}$ for $72 \mathrm{~h}$. Subsamples of freshly washed roots were stained using the methods of Guttenberger (2000) and viewed with a microscope for evidence of mycorrhizal colonization.

\section{Statistical analysis}

For both amendments, the design was a split plot in which irrigation frequency (twice a day for $3 \mathrm{~min}$, three times a day for $2 \mathrm{~min}$ ) was the main effect; amendment, the subplot (Nitragin, none; or AM, none); and fertilizer rate $\left(8,16,24\right.$, or $\left.32 \mathrm{~mL} \cdot \mathrm{L}^{-1}\right)$, the sub-subplot. Each combination of treatments was replicated three times. There were 48 trays for experiments with each amendment, with each tray representing a replication for a combination of variables. Data were subjected to analysis of variance in Statistical Analysis System (SAS, Cary, N.C.) to determine the significance of main and interaction effects. When present, interactions were given preference to explain results, and if they contained a component that was quantitative and continuous, data were subjected to regression analysis. If regression analysis was not appropriate, data were plotted and differences between points compared using SE. When appropriate, the Ryan-Einot-Gabriel-Welsch multiple F test was used to separate means. Pearson product moment correlation analysis was performed to determine the association of plant height and dry weight.

\section{Results}

Although not observed on a continuous basis, visual observation at random times did not indicate that any plants suffered from stress as a result of drought or disease.

\section{Bacterial amendment}

Plant height and dry weight were affected by main effects and interactions (Table 3 ). Amendment with bacteria did, but fertilizer rate and irrigation regime did not, affect plant

Table 1. Values for constituents ${ }^{\mathrm{z}}$ of the irrigation water used in the greenhouse.

\begin{tabular}{|c|c|c|c|c|c|c|c|c|c|c|c|c|}
\hline $\mathrm{pH}$ & $\begin{array}{l}\mathrm{NO}_{3}-\mathrm{N} \\
\left(\mu g \cdot g^{-1}\right)\end{array}$ & $\begin{array}{c}\mathrm{K} \\
\left(\mu \mathrm{g} \cdot \mathrm{g}^{-1}\right)\end{array}$ & $\begin{array}{c}B \\
\left(\mu g \cdot g^{-1}\right)\end{array}$ & $\begin{array}{c}\mathrm{Ca} \\
\left(\mu \mathrm{g} \cdot \mathrm{g}^{-1}\right)\end{array}$ & $\begin{array}{c}\mathrm{Cl} \\
\left(\mu \mathrm{g} \cdot \mathrm{g}^{-1}\right)\end{array}$ & $\begin{array}{c}\mathrm{Na} \\
\left(\mu \mathrm{g} \cdot \mathrm{g}^{-1}\right)\end{array}$ & $\begin{array}{l}\mathrm{CaCO}_{3} \\
\left(\mu g \cdot g^{-1}\right)\end{array}$ & $\begin{array}{c}\text { Alkalinity } \\
{\left[\text { as } \mathrm{CaCO}_{3}\right.} \\
\left.\left(\mu \mathrm{g} \cdot \mathrm{g}^{-1}\right)\right]\end{array}$ & $\begin{array}{c}\mathrm{Mg} \\
\left(\mu \mathrm{g} \cdot \mathrm{g}^{-1}\right)\end{array}$ & $\begin{array}{c}\mathrm{SO}_{4} \\
\left(\mu \mathrm{g} \cdot \mathrm{g}^{-1}\right)\end{array}$ & $\begin{array}{c}\text { Hardness } \\
\left(\mu g \cdot g^{-1}\right)\end{array}$ & $\begin{array}{c}\text { EC } \\
\left(\mu \mathrm{mhos} \cdot \mathrm{cm}^{-1}\right)\end{array}$ \\
\hline 7.0 & $<1$ & 2 & 0.07 & 13 & 15 & 16 & 41 & 4 & 2 & 12 & $39^{y}$ & 151 \\
\hline
\end{tabular}

${ }^{\mathrm{z} A n a l y s e s ~ p e r f o r m e d ~ b y ~ t h e ~ O k l a h o m a ~ S t a t e ~ U n i v e r s i t y ~ S o i l, ~ W a t e r ~ \& ~ F o r a g e ~ A n a l y t i c a l ~ L a b o r a t o r y, ~ S t i l l w a t e r, ~ O k l a . ~}$

${ }^{\mathrm{y}}$ Hardness class is soft.

Table 2. Values for constituents ${ }^{\mathrm{z}}$ of the Sunshine potting medium and the Neptune's Harvest fertilizer diluted in the irrigation water.

\begin{tabular}{|c|c|c|c|c|c|c|c|c|c|c|c|c|c|c|}
\hline Source & $\mathrm{pH}$ & $\begin{array}{c}\mathrm{NH}_{3} \\
\left(\mu \mathrm{g} \cdot \mathrm{g}^{-1}\right)\end{array}$ & $\begin{array}{l}\mathrm{NO}_{3}-\mathrm{N} \\
\left(\mu g \cdot g^{-1}\right)\end{array}$ & $\begin{array}{c}P \\
\left(\mu g \cdot g^{-1}\right)\end{array}$ & $\begin{array}{c}\mathrm{K} \\
\left(\mu \mathrm{g} \cdot \mathrm{g}^{-1}\right)\end{array}$ & $\begin{array}{c}\text { B } \\
\left(\mu g \cdot g^{-1}\right)\end{array}$ & $\begin{array}{c}\mathrm{Ca} \\
\left(\mu \mathrm{g} \cdot \mathrm{g}^{-1}\right)\end{array}$ & $\begin{array}{c}\mathrm{Cu} \\
\left(\mu \mathrm{g} \cdot \mathrm{g}^{-1}\right)\end{array}$ & $\begin{array}{c}\mathrm{Fe} \\
\left(\mu \mathrm{g} \cdot \mathrm{g}^{-1}\right)\end{array}$ & $\begin{array}{c}\mathrm{Na} \\
\left(\mu \mathrm{g} \cdot \mathrm{g}^{-1}\right)\end{array}$ & $\begin{array}{c}\mathrm{Mg} \\
\left(\mu \mathrm{g} \cdot \mathrm{g}^{-1}\right)\end{array}$ & $\begin{array}{c}\mathrm{SO}_{4} \\
\left(\mu \mathrm{g} \cdot \mathrm{g}^{-1}\right)\end{array}$ & $\begin{array}{c}\mathrm{Zn} \\
\left(\mu \mathrm{g} \cdot \mathrm{g}^{-1}\right)\end{array}$ & $\begin{array}{c}\mathrm{EC} \\
\left(\mu \mathrm{mhos} \cdot \mathrm{cm}^{-1}\right)\end{array}$ \\
\hline Potting medium & 6.1 & 69.7 & 85 & 8.4 & 22 & 0.1 & 100 & 1.0 & 14.5 & 29 & 59 & 90 & 1.2 & 1425 \\
\hline Neptune's Harvest & & 5.7 & 8.9 & $<1$ & 97.0 & 25 & 0.1 & 30 & $-\mathrm{y}$ & 79 & 3 & 21 & - & 657 \\
\hline
\end{tabular}

${ }^{\mathrm{z}}$ Analyses performed by the Oklahoma State University Soil, Water \& Forage Analytical Laboratory, Stillwater, Okla. Results for the fertilizer are for the $1 \times$ rate diluted in the irrigation water, which should be multiplied by $2,4,6$, or 8 to correspond to the rates used.

yot analyzed. 
Table 3. Analysis of variance (ANOVA) table for heights and dry weights of bell pepper seedlings produced in a medium amended with a mixture of Sinorhizobium bacteria under different irrigation regimes and at varying fertilizer rates.

\begin{tabular}{|c|c|c|}
\hline \multirow[b]{2}{*}{ Source } & \multicolumn{2}{|c|}{ Plant } \\
\hline & $\mathrm{Ht}$ & Dry wt \\
\hline$\overline{\text { Amendment }(\mathrm{A})^{\mathrm{z}}}$ & ** & $* *$ \\
\hline Fertilizer rate $(\mathrm{F})$ & NS & NS \\
\hline Irrigation regime (I) & NS & NS \\
\hline \multicolumn{3}{|l|}{ Interaction $^{y, x}$} \\
\hline $\mathrm{I} \times \mathrm{F}$ & ** & ** \\
\hline$A \times F$ & $*$ & NS \\
\hline$A \times I$ & ns & ** \\
\hline
\end{tabular}

${ }^{\mathrm{z}}$ The bacterial inoculant used was Nitragin ${ }^{\circledR}$.

${ }^{\mathrm{y}}$ Shown are the significant interactions only.

${ }^{\mathrm{x}}$ Values for the interactions did not conform to linear distributions.

NS,*,**Nonsignificant or significant at $P \leq 0.05$ or $P \leq 0.01$, ANOVA.

height or dry weight. The interaction of irrigation regime $\times$ fertilizer rate affected plant height and weight, and the amendment $\times$ fertilizer rate and the amendment $\times$ irrigation regime interactions effected plant height or dry weight. In the amendment $\times$ irrigation regime interaction, amendment did not affect height. In the fertilizer rate $\times$ biotic amendment, interaction did not affect weight. By itself, use of bacteria increased height and plant dry weight over untreated controls (Table 4).

When irrigated twice a day, plant height increased when $16 \mathrm{~mL} \cdot \mathrm{L}^{-1}$ of fertilizer was used (Fig. 1A). At higher fertilizer rates, plant height declined. When irrigated three times a day, plant height increased when $16 \mathrm{~mL} \cdot \mathrm{L}^{-1}$ of fertilizer was used, was lower at the 24 $\mathrm{mL} \cdot \mathrm{L}^{-1}$ rate, and was higher at the $32 \mathrm{~mL} \cdot \mathrm{L}^{-1}$ rate, than for the twice-a-day irrigation. Plant dry weight followed the same trend as plant height (Fig. 1B).

Over fertilizer rates, plants were tallest when treated with bacteria than for controls (Fig. 2). When irrigated twice a day, there were no differences in plant dry weight, but when plants treated with bacteria were irrigated three times a day, they were heavier
Table 4. Effect of bacterial amendment on bell pepper transplant height and dry weight.

\begin{tabular}{lcc}
\hline Amendment & $\mathrm{Ht}(\mathrm{mm})$ & Dry wt $(\mathrm{g})$ \\
\hline Bacteria & $133 \mathrm{a}^{\mathrm{z}}$ & $0.30 \mathrm{a}$ \\
None & $114 \mathrm{~b}$ & $0.26 \mathrm{~b}$ \\
\hline
\end{tabular}

${ }^{2}$ Values in a column followed by the same letter are not significantly different. $P \leq 0.05$, Ryan-EinotGabriel-Welsch multiple F test.

than controls (Fig. 3). There was no visual indication of presence of nodules.

\section{AM amendment}

Plant height and dry weight were unaffected by main effects, but were affected by interactions (Table 5). The fertilizer rate $x$ irrigation frequency interaction affected plant height and dry weight. The amendment $\times$ fertilizer rate and the amendment $\times$ irrigation frequency interactions affected plant height or dry weight.

When irrigated twice a day, plants were tallest when they were treated with $24 \mathrm{~mL} \cdot \mathrm{L}^{-1}$ fertilizer, and when irrigated three times a day, the tallest plants were those treated with $16 \mathrm{~mL} \cdot \mathrm{L}^{-1}$ of fertilizer (Fig. 4A). All plants had reduced heights when treated with $32 \mathrm{~mL} \cdot \mathrm{L}^{-1}$ of fertilizer. When irrigated twice a day, plants were heaviest when they received 16 or $24 \mathrm{~mL} \cdot \mathrm{L}^{-1}$ of fertilizer, whereas those irrigated three times a day were heaviest when they received $16 \mathrm{~mL} \cdot \mathrm{L}^{-1}$ of fertilizer (Fig. 4B).

The AM-treated and control plants were tallest when they received $16 \mathrm{~mL} \cdot \mathrm{L}^{-1}$ of fertilizer (Fig. 5A). Controls had taller plants than those treated with AM. Control plants were heaviest when treated with $16 \mathrm{~mL} \cdot \mathrm{L}^{-1}$ of fertilizer, and plants treated with AM were when treated with 24 or $32 \mathrm{~mL} \cdot \mathrm{L}^{-1}$ of fertilizer than controls (Fig. 5B). There was no microscopic evidence of the presence of mycorrhizae in cells of roots.

\section{Association of plant height and dry weight}

Overall treatment plant height and dry weight were correlated for plants in the bacterial amendment experiment (Table 6). For specific treatment combinations-1) no bacterial amendment, irrigation three times a day, $24 \mathrm{~mL} \cdot \mathrm{L}^{-1}$ of fertilizer; and 2 ) bacterial amendment, irrigation twice a day, 32 $\mathrm{mL} \cdot \mathrm{L}^{-1}$ of fertilizer-plant height and dry weight were correlated. Overall treatments plant height and dry weight were correlated for plants in the AM amendment experiment (Table 6). For specific treatment combinations-1) no AM amendment, irrigation twice a day, and $32 \mathrm{~mL} \cdot \mathrm{L}^{-1}$ of fertilizer; 2) 24 or $32 \mathrm{~mL} \cdot \mathrm{L}^{-1}$ of fertilizer, irrigation twice a day; and 3) AM amendment, $16 \mathrm{~mL} \cdot \mathrm{L}^{-1}$ of fertilizer, irrigation three times a day-plant height and dry weight were correlated.

\section{Discussion}

Vegetable transplant development can be manipulated in the production system. The current project was undertaken to determine the efficacy of biological amendments in the production of bell pepper transplants, and to determine whether effects were modified by irrigation frequency and fertilizer rate. The materials can be used in an organic system. The $\mathrm{pH}$ of the irrigation water, the medium, and the fertilizer in solution at each application should have had minimal affects on the biological amendments.

Transplant size is important in commercial operations because plants must be able to be placed in the ground using mechanical means. The transplants produced fit that criterion for both amendments and controls. Results were modified by irrigation frequency and fertilizer rate. Overall plant height was correlated with plant dry weight; however, this was the result of pooling data. There were indications that correlation of overall treatments masked the contributions of specific combinations of factors. When they existed, most correlations were when the higher fertilizer rates were used regardless of irrigation regime. However, fertilization at the higher rates did not necessarily produce the tallest or heaviest plants. Fertilizer rates
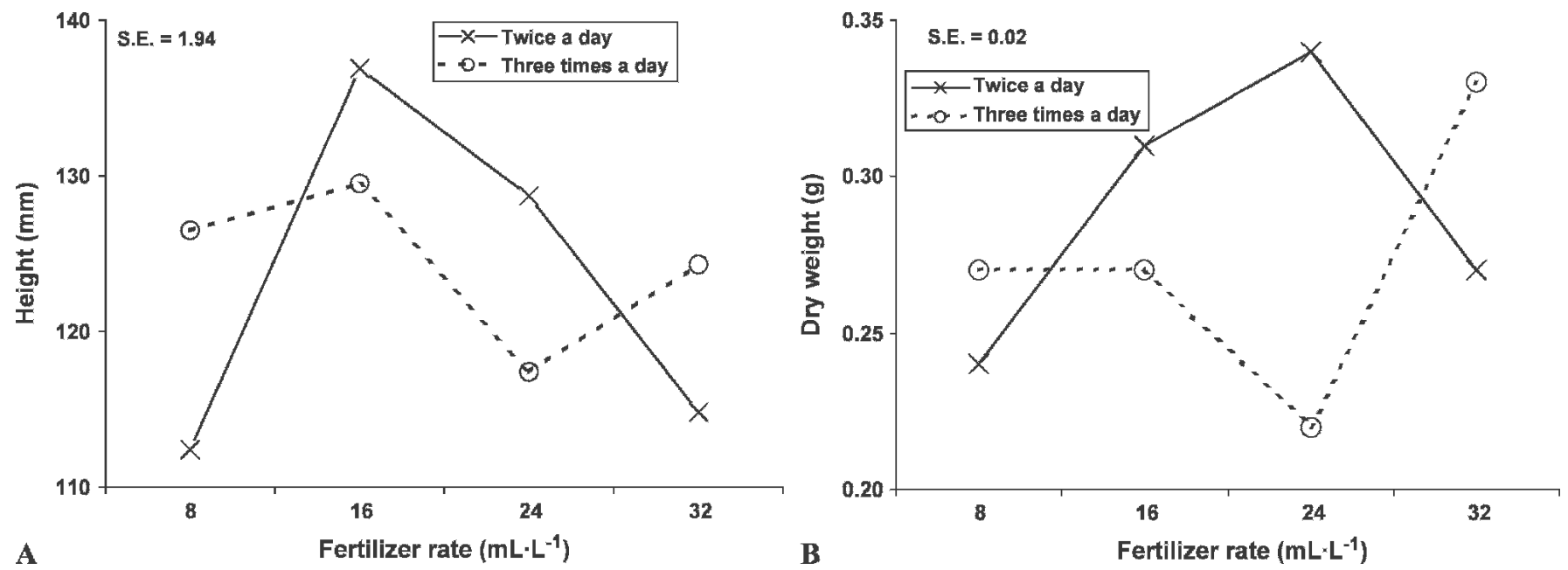

Fig. 1. Height (A) and dry weight $(\mathbf{B})$ as a result of the irrigation frequency $\times$ fertilizer rate interaction for plants in a medium amended, or not, with Nitragin ${ }^{\circledR}$ mix containing Sinorhizobium sp. Data did not fit L, Q, or C distributions (see Table 3). 


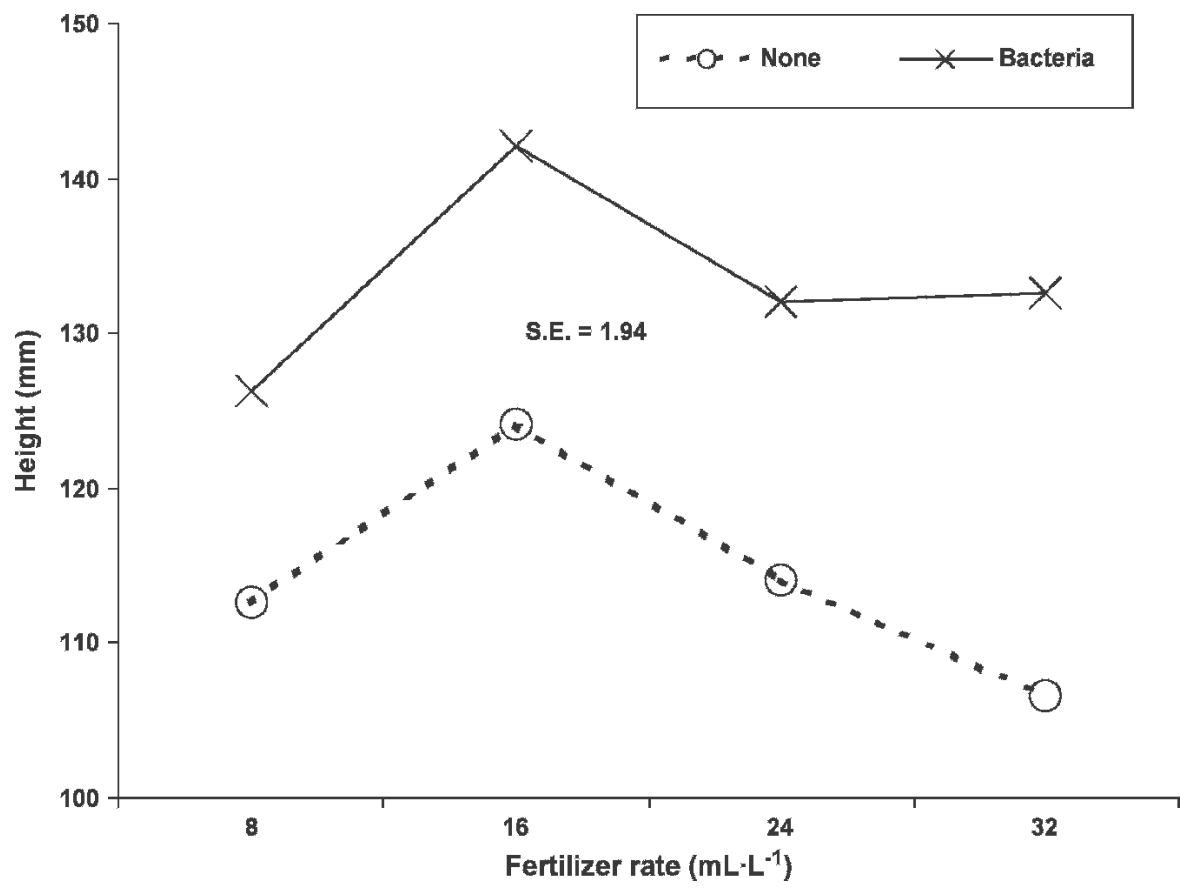

Fig. 2. Plant height as a result of the amendment $\times$ fertilizer rate interaction for plants in a medium amended, or not, with Nitragin ${ }^{\circledR}$ mix containing Sinorhizobium sp. Data did not fit L, Q, or C distributions (see Table 3).

may be used to regulate plant height and produce plants that are more balanced with regard to height and biomass.

Use of bacteria appeared to increase seedling height and dry weight. Even if bacteria do not infect plant tissues, they are capable of changing the rhizosphere in a way that could contribute to an environment beneficial to plant development (Dobbelaere et al., 2003; Gross and Vidaver, 1978). The method by which this may happen for Sinorhizobium sp., which are generally not considered to be free living $\mathrm{N}_{2}$ fixers, is not clear.

The efficacy of Myco-VAM as an amendment is less clear. Further research is required to understand better the reasons for the limitations. It may be that the $\mathrm{P}$ level in the potting medium and the fertilizer reduced AM efficacy. However, at some fertilizer

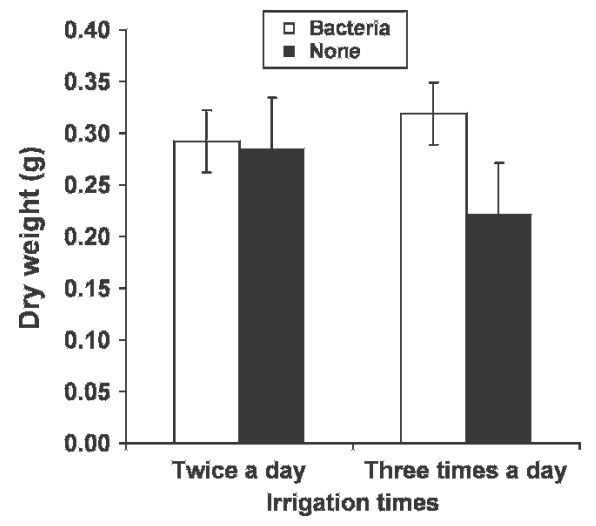

Fig. 3. Dry weight as a result of the amendment $x$ irrigation frequency interaction for plants in a medium amended, or not, with Nitragin ${ }^{\circledR}$ mix containing Sinorhizobium sp. at each fertilizer rate.

Table 5. Analysis of variance (ANOVA) table for height and dry weight of bell pepper seedlings produced in a medium amended with inoculant containing Arbuscular mycorrhizae fungi under different irrigation regimes and varying rates of fertilizer.

\begin{tabular}{lcc}
\hline & \multicolumn{2}{c}{ Plant } \\
\cline { 2 - 3 } Source & Ht & Dry wt \\
\hline Amendment $(\mathrm{A})^{\mathrm{z}}$ & $\mathrm{NS}$ & $\mathrm{NS}$ \\
Irrigation regime (I) & $\mathrm{NS}$ & NS \\
Fertilizer rate $(\mathrm{F})$ & & \\
Interaction & & $* *$ \\
$\quad \mathrm{~F} \times \mathrm{I}$ & $* *$ & $* *$ \\
$\mathrm{~A} \times \mathrm{F}$ & $\mathrm{NS}$ & NS \\
$\mathrm{A} \times \mathrm{I}$ & $*$ &
\end{tabular}

${ }^{z}$ Fungal inoculant used was Myco-VAM ${ }^{\circledR}$.

yShown are the significant interactions only.

${ }^{x}$ Values for the interactions did not conform to linear distribution.

NS,*,**Nonsignificant or significant at $P \leq 0.05$ or $P \leq 0.01$, ANOVA. attributable to $G$. intraradices. How AM fungi might be affecting developing roots in the potting medium in transplant trays is not clear. When transplanted, even if infection by $\mathrm{AM}$ is low, conditions in the field may favor AM colonization. Also, it may be that indigenous levels of AM fungi in soils may compensate for lack of infection in the greenhouse (Hamel et al., 1997; Sieverding, 1991).

Like that reported by Russo (2005) for another alternative fertilizer, Neptune's Harvest should be used at a rate higher, but no
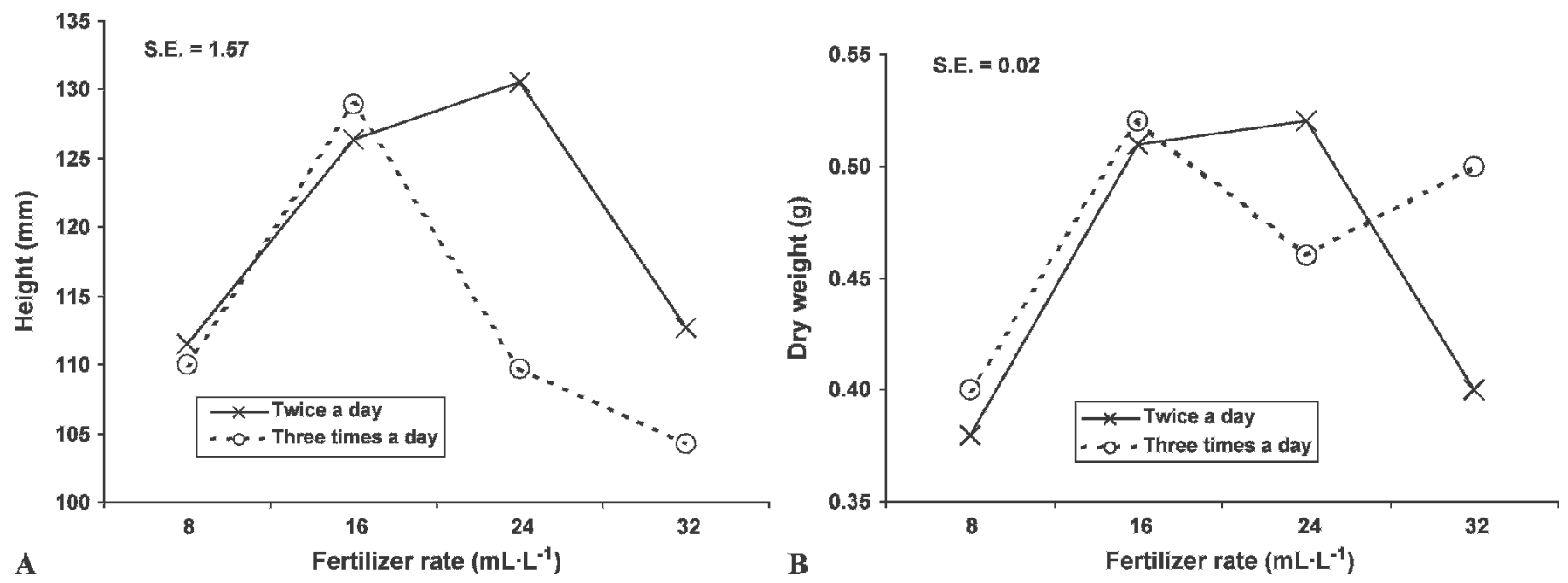

Fig. 4. Plant height (A) and dry weight $(\mathbf{B})$ for plants as a result of the irrigation frequency $\times$ fertilizer rate interaction in a medium amended, or not, with Myco-VAM ${ }^{\circledR}$ mix containing arbuscular mycorrhizae fungi. Data did not fit L, Q, or C distributions (see Table 5). 

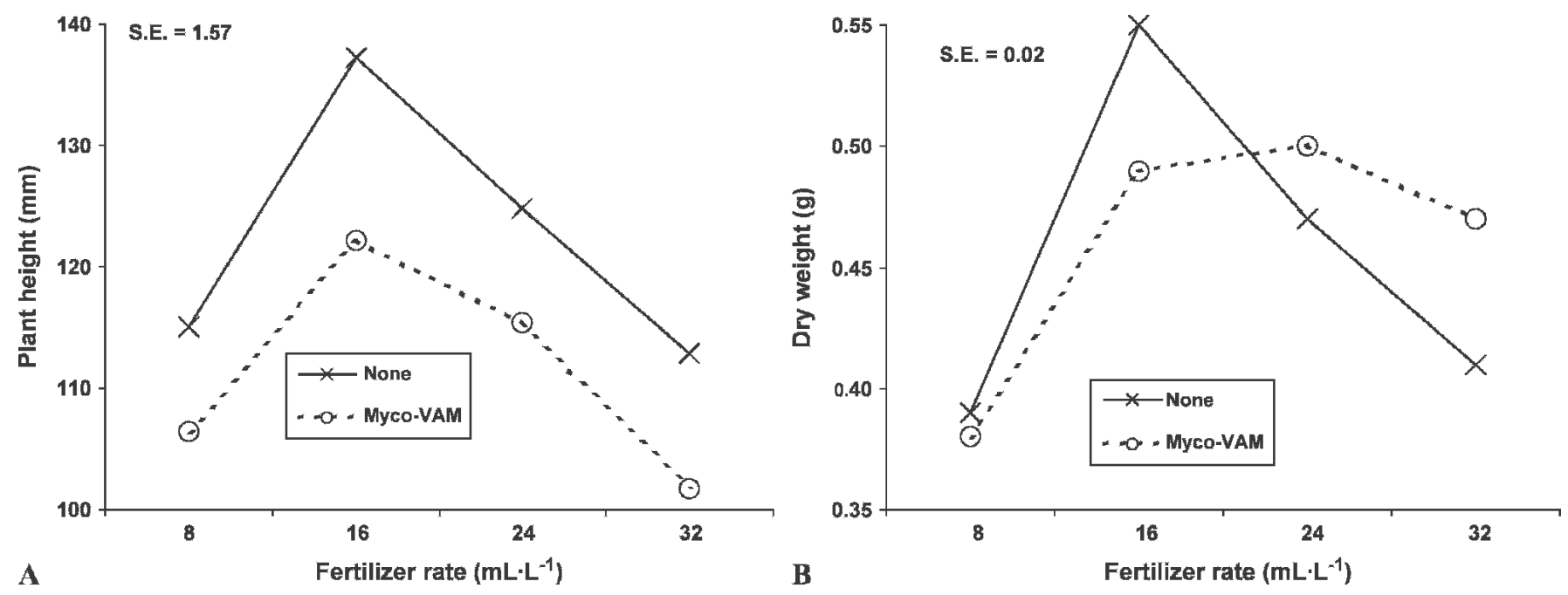

Fig. 5. Plant height $(\mathbf{A})$ and dry weight $(\mathbf{B})$ as a result of the amendment $\times$ fertilizer rate interaction for plants in a medium amended, or not, with Myco-VAM ${ }^{\circledR}$. Data did not fit L, Q, or C distributions (see Table 5).

Table 6. Pearson product moment correlations of the association of height and dry weight for plants treated, or not, with amendments and with different irrigation frequencies and fertilizer rates.

\begin{tabular}{|c|c|c|c|c|}
\hline \multicolumn{3}{|c|}{ Bacterial amendment } & $r$ & $P$ \\
\hline \multicolumn{3}{|c|}{ Overall Treatments } & & \\
\hline Amendment & Irrigation frequency & Fertilizer rate & 0.2332 & $<0.0001$ \\
\hline None & Three times a day & $24 \mathrm{~mL} \cdot \mathrm{L}^{-1}$ & 0.4192 & 0.0211 \\
\hline Bacteria & Twice a day & $32 \mathrm{~mL} \cdot \mathrm{L}^{-1}$ & 0.3686 & 0.0450 \\
\hline \multicolumn{3}{|c|}{ Arbuscular mycorrhizae (AM) amendment } & $r$ & $P$ \\
\hline \multicolumn{3}{|c|}{ Overall treatments } & & \\
\hline Amendment & Irrigation frequency & $\overline{\text { Fertilizer rate }}$ & 0.2791 & $<0.0001$ \\
\hline None & Twice a day & $32 \mathrm{~mL} \cdot \mathrm{L}^{-1}$ & 0.5356 & 0.0023 \\
\hline AM & Twice a day & $24 \mathrm{~mL} \cdot \mathrm{L}^{-1}$ & 0.4956 & 0.0054 \\
\hline $\mathrm{AM}$ & Twice a day & $32 \mathrm{~mL} \cdot \mathrm{L}^{-1}$ & 0.4251 & 0.0062 \\
\hline $\mathrm{AM}$ & Three times a day & $16 \mathrm{~mL} \cdot \mathrm{L}^{-1}$ & 0.6566 & $<0.0001$ \\
\hline
\end{tabular}

more than six times, than that indicated on the label. Use of Neptune's Harvest, in conjunction with an appropriate irrigation regime, and a potting medium that meets NOP standards, will provide a complete organic method for production of bell pepper transplants, and this technique could likely be applied to other crops. Addition of Sinorhizobium bacteria provided a benefit to transplant height and, over fertilizer rates, generally improved dry weight over untreated controls. Nodules, which were not expected to be formed, were not found. It remains to be determined whether other bacteria will affect seedling development. Further research is needed to determine whether plants developed from seedlings in bacteria or AM-amended potting mix are different from untreated controls when seedlings are established in the field.

\section{Literature Cited}

Andrews, M., E.K. James, S.P. Cummings, A.A Zavalin, L.V. Vinogradova, and B.A. McKenzie. 2003. Use of nitrogen fixing bacteria inoculants as a substitute for nitrogen fertilizer for dryland graminaceous crops: Progress made, mechanisms of action and future potential. Symbiosis 35: 209-229.

Cantliffe, D.J. 1993. Pre- and postharvest practices for improved vegetable transplant quality. HortTechnology 3:415-418.
Damato, G. and L. Trotta. 2000. Cell shape, transplant age, cultivars and yield in broccoli. Acta Hort. 533:153-160.

de Grazia, J., P. Tittonell, and A. Chiesa. 2002. Pepper (Capsicum annuum L.) transplant growth as affected by growing medium compression and cell size. Agronomie 22:503-509.

Dobbelaere, S., J. Vanderleyden, and Y. Okon. 2003. Plant growth-promoting effects of diazotrophs in the rhizosphere. Crit. Rev. Plant Sci. 22:107-149.

Douds, Jr., D.D. and C. Reider. 2003. Inoculation with mycorrhizal fungi increases the yield of green peppers in a high P soil. Biol. Agr. Hort. 21:91-102.

Dufault, R.J. 1998. Vegetable transplant nutrition. HortTechnology 8:515-523.

Emitiazi, G., Z. Etemadifar, and M. Tavassoli. 2003. A novel nitrogen-fixing cellulitic bacterium associated with root of corn is a candidate for production of single cell protein. Biomass Bioenergy 25:423-426.

Glick, B.R. 2004. Changes in plant growth and development by rhizosphere bacteria that modify plant ethylene levels. Acta Hort. 631:265273.

Gross, D.C. and A.K. Vidaver. 1978. Bacteriocinlike substances produced by Rhizobium japonicum and other slow-growing rhizobia. Appl. Environ. Microbiol. 36:936-943.

Guttenberger, M. 2000. A rapid staining procedure for arbuscules of living arbuscular mycorrhizas using neutral red as acidotropic dye. Plant Soil 226:211-218.
Hamel, C., Y. Dalpé, V. Furlan, and S. Parent 1997. Indigenous populations of arbuscular mycorrhizal fungi and soil aggregate stability are major determinants of leek (Allium porrum L.) response to inoculation with Glomus intraradices Schenk and Smith or Glomus veisiforme (Karsten) Berch. Mycorrhiza 7:187-196.

Hartz, T.K., C. Giannini, E.M. Miyao, and J.G. Valencia. 2002. Divergent transplant production practices produce compatible growth, yield, and quality of processing tomatoes. HortScience 37:296-299.

Koeller, M., T. Alfoldi, M. Siegrist, and F. Weibel. 2004. A comparison of plant and animal based fertiliser for the production of organic vegetable transplants. Acta Hort. 631:209-215.

Kokalis-Burelle, N., J.W. Klopper, R. RodriguezKábana, C.S. Vavrina, E.N. Rosskopf, and D.S Kenney. 1999. Evaluation of amended transplant mixes for fruit and vegetable production. http://www.epa.gov/ozone/mbr/airc/1999/ 83burell.pdf. Accessed 24 Aug. 2005.

Kokalis-Burelle, N., C.S. Vavrina, M.S. Reddy, and J.W. Klopper. 2003. Amendment of muskmelon and watermelon transplant media with plant growth-promoting rhizobacteria: Effects on seedling quality, disease, and nematode resistance. HortTechnology 13:476-482.

Koller, M., T. Alfoldi, M. Siegrist, and F. Weibel 2004. A comparison of plant and animal based fertiliser for the production of organic vegetable transplants. Acta Hort. 631:209-215.

Linderman, R.G. and E.A. Davis. 2001. Vesiculararbuscular mycorrhiza and plant growth responses to soil amendment with composted grape pomace or its water extract. HortTechnology 11:446-450.

Linderman, R.G. and E.A. Davis. 2003. Arbuscular mycorrhiza and growth responses of several ornamental plants grown in soilless peat-based medium amended with coconut dust (coir) HortTechnology 13:482-487.

Lucy, M., E. Reed, and B.R. Glick. 2004. Applications of free living plant growth-promoting rhizobacteria. Antonie Van Leeuwenhoek 86:1-25.

Makus, D.J. 2005. Effect of mulch, mycorrhizal inoculation, and surround on late fall pepper production. HortScience 40:999 (Abstr.).

Martin, C.A. and J.C. Stutz. 2004. Interactive effects of temperature and arbuscular mycorrhizal fungi on growth, $\mathrm{P}$ uptake and root 
respiration of Capsicum annuum L. Mycorrhiza $14: 241-244$

Maynard, D.N. 2000. Triploid watermelon transplant production. Acta Hort. 533:109-112.

Nemec, S., L.E. Datnoff, and J. Strandberg. 1996. Efficacy of biocontrol agents in planting mixes to colonize plant roots and control root diseases of vegetables and citrus. Crop Prot. 15:735742 .

Nicola, S., J. Hoeberechts, and E. Fontana. 2004. Studies on irrigation systems to grow lettuce (Lactuca sativa L.) transplants. Acta Hort. 631:141-148.

Rippy, J.F.M., M.M. Peet, F.J. Louws, P.V. Nelson, D.B. Orr, and K.A. Sorensen. 2004. Plant development and harvest yield of greenhouse tomatoes in six organic growing systems. HortScience 39:223-229.

Russo, V.M. 2004. Greenhouse-grown transplants as an alternative to bare-root transplants for onion. HortScience 39:1267-1271.

Russo, V.M. 2005. Organic vegetable transplant production. HortScience 40:623-628.

Schulze, J. and G. Pöschel. 2004. Bacterial inoculation of maize affects carbon allocation to roots and carbon turnover in the rhizosphere. Plant Soil 267:235-241.

Shimshick, E.J. and R.R. Herbert. 1979. Binding characteristics of N2-fixing bacteria to cereal roots. Appl. Environ. Microbiol. 38:447-453.

Sieverding, E. 1991. Vesicular-arbuscular mycorrhiza management in tropical agrosystems. Deutsche Gesellscharft für Technische Zusammansabeit (GT2) Gmbh. Eschbon, Germany.

Singh, R. and A. Adholeya. 2002. Plant and fungal responses to colonization, p. 213-230. In: A.K. Sharma, and B.N. Johri (eds.). Arbuscular mycorrhizae: Interactions in plants, rhizosphere, and soils. Science Publishers, Enfield, N.H.

Sterrett, S.B., C.W. Reynolds, F.D. Schales, R.L. Chaney, and L.W. Douglass. 1983. Transplant quality, yield, and heavy-metal accumulation of tomato, muskmelon, and cabbage grown in media containing sewage sludge compost. J. Amer. Soc. Hort. Sci. 108:36-41.

Suresh, C.K. and D.J. Bagyaral. 2002. Mycorrhizamicrobe interactions: Effect on rhizosphere, p. 7-28. In: A.K. Sharma, and B.N. Johri (eds.). Arbuscular mycorrhizae: Interactions in plants, rhizosphere and soils. Science Publishers, Enfield, N.H

United States Department of Agriculture, Agriculture Marketing Service. 21 Dec. 2000. National Organic Program: Final rule. 7 CFR Part 205. Federal Register.

Vavrina, C.S. 1998. Transplant age in vegetable crops. Horttechnology 8:550-555.

Vavrina, C.S. and P.D. Roberts. 2004. Use of commercial systemic resistance (SAR) inducers in the stand establishment of tomato: Impact of plant growth, disease and nematode suppression. Acta Hort. 631:231-238.

Waterer, D.R. and R.R. Coltman. 1989. Response of mycorrhizal bell peppers to inoculation timing, phosphorus, and water stress. HortScience 24:688-690.

Zahir, Z.A., M. Arshad, and W.T. Frankenberger. 2004. Plant growth promoting rhizobacteria: Applications and perspectives in agriculture. Adv. Agron. 81:97-168.

Zehnder, G.W., J.F. Murphy, E.J. Sikora, and W. Klopper. 2001. Application of rhizobacteria for induced resistance. Eur. J. Plant Pathol. 107:39-50. 